\title{
Vilija Stanišauskienè
}

Kaunas University of Technology, Kaunas, Lithuania

e-mail: vilija.stanisauskiene@ktu.It

\section{Aistè Urbonienè}

Vilnius University, Kaunas, Lithuania

e-mail: aiste.urboniene@khf.vu.It

\section{Dynamics of Learning Motives and Barriers in the Context of Changing Human Life Roles}

\begin{abstract}
This paper promotes a theoretical discussion that focuses on the motives and barriers that make impact on adults learning as well as on their dynamics related to the change of social roles. The adult learning motives and barriers change and vary according to the prevailing social roles at different periods of one's life. This dynamics of adult learning motives and barriers is mostly influenced by the importance and compatibility of acquired social roles, responsibility areas and spaces of a person and other factors. The qualitative data was gathered in March - April 2016 in Kaunas, Lithuania. The sample consisted of 30 narratives, written by informants, aged 35 to 65 years that were participating in professional training courses. There has been prepared 30 self-reflections that were analysed using content analysis. The analysis of empirical data shows that external learning motives and barriers prevail in the period when an individual is active in the labour market while the personal motives remain overshadowed. However, personal barriers prevail in the expression of learning barriers. This is influenced by the society's attitude towards the performance of pupil and student roles and the value attitudes of surrounding people that partially control it.
\end{abstract}

Keywords: learning motives learning, barriers, life roles 


\section{Introduction}

Rapid changes in the labour market that are influenced by the new technologies and global tendencies encourage the need for lifelong adult learning. In the modern knowledge society, the need for lifelong learning is one of its development conditions, which helps to realize the objectives of active citizenship, social integration, participation in the labour market and personal fulfilment. Due to the variety of life roles, specifics of career activities, the acquired experience and other factors, adult learning essentially differs from children learning. In order to involve adults in the lifelong learning process, it is important to evaluate their learning motives and determine the dominating barriers.

The motivation of adult lifelong learning has attracted a lot of attention of the researchers. Many scholars (Chao, 2009; Drucker, 1993; Gage Berlin, 1992; Sogunro, 2015; Stipek, 2002) analysed the adult learning motives and factors that determine its dynamics.

Career development theories (Savickas, Nota, Rossier, 2009) stress the dynamics of social roles and the necessity to combine them in order to achieve self-fulfilment, improve life quality and prevent professional burnout. In such stages of life when a person has a variety of equally important and energy consuming social roles (employee, father/mother, child of his/her parents and other) specific learning barriers and motives may be revealed. However, there is a lack of researches, which reveal the link between adult learning motives and barriers and the performed social roles.

This helps to form the research questions: what motives encourage adults to learn? What barriers hinder their learning? How are the adult learning motives and barriers and their dynamics related to the change of social roles? Thus, the aim of this research is to reveal the dynamics of learning motives and barriers in the context of changing human life roles.

The following data gathering methods were used in this research: scientific literature analysis and reflection writing. The gathered data were analysed by applying qualitative content analysis. This article is composed of three parts. The first part provides scientific literature analysis revealing the peculiarities of factors that influence adult learning and their connection to the change of social roles. The second part presents 
methodology of the research. The third part of the article provides and interprets research results and conclusions.

\section{Specifics of Factors Influencing Adult Learning and the Link to Changing Life Roles}

The adult learning differs from children learning essentially due to different psychosocial maturity, the acquired experience and responsibilities of learners. These differences influence the adult learning motives and barriers as well (Trivette et al., 2009; Stanišauskienè, 2007). According to Rubenson (2011), self-direction, orientation towards problem solving and learning selection and reliance on own experience are peculiar to the adult learning. Self-direction that is peculiar to adult learning stresses the importance of inner motivation. Self-directed learning is "a process by which people identify their learning needs, set goals, choose how to learn, gather materials, and evaluate their progress" (Rubenson, 2011, p. 53). Thus, meta-learning competence and sufficient motivation are needed for self-directed learning.

Adult learning is oriented towards problem solving, i.e., learning motivation is related to the problems arising in various spheres of life. Only in rare cases, adults learn because learning is a pleasant activity. Usually, adults are interested in the content of learning that directly influences their lives. They want to foresee how learning will help to solve their career, health and other problems from different life areas.

Adults select learning content very carefully. Children are learning according to the set programme in schools, because they cannot decide what to learn due to their limited knowledge experience; whereas, adults invest their time, energy and other resources only into something that is important to them. According to Rubenson (2011, p. 49), adults are not very inclined to learn something they are not interested in, or in which they cannot see the meaning and importance. Children believe that what they are learning will be useful in their distant future; while, adults think that what they are learning will be useful instantly.

Learning from experience is peculiar to adults (Kilroy, 2004; Ramsay, Sorrell, 2007). In contrast to children, adults have more life, work and learning experiences. In the process of learning, they evaluate the pro- 
vided information from the perspective of an experienced person. Thus, active methods of learning that encourage learners to reflect on their experience, analyse cases and evaluate situations are suitable for adults. Due to the experience of learning adults, the relation between teacher and learners is mutual and equal: participants of trainings can become the source of knowledge to their teacher and other learners.

Thus, the question is what are the motives and barriers of adult learning. Motives are the incentives of activities related to the fulfilment of individual needs: 1) inner and outer factors encouraging the activity of an individual and determining the direction of personal activity; 2) material and ideal aims of an individual; 3 ) the reasons for choosing individual actions and behaviours that are realised by the person (Psichologijos žodynas, 1993, p. 177).

It is widely accepted that there are two types of learning motives: external and internal. External learning motives are used when it has been decided to learn not because learning is pleasant, but because learning (its result) leads towards something useful and meaningful, for example, qualification improvement, when expecting a promotion. Internal learning motives appear when learning is performed expecting positive learning experience, individual is oriented towards personal growth and self-realisation.

Knasel et al. (2000) distribute learning motives into two groups as well. According to these authors, motives can be reactive and proactive. Reactive motives appear when learning is a response to faced difficulties or in order to remain in the work place. Proactive learning motives appear when a person learns something that is likely to be useful in the future. If internal and proactive learning motives dominate, learning provides more happiness and is more effective. If reactive learning motives dominate, the learning process has to be planned in detail foreseeing interim results, ways of self-control and self-encouragement.

According to Chao (2009, p. 910), learning motivation of adults can be categorized into three groups of motives: 1) work/economic motives (higher earning potential, professional advancement and work retention), social (communication improvement, social contacts etc.) and personal (cognitive interest, family togetherness, social stimulation).

The factors that hinder learning are named as learning barriers and, as Chao (2009) claims, they appear in two spaces, i.e., personal and social, 
that are created and formed by different factors as well. Some authors divide adult learning barriers into four groups: personal, practical, organisational and social (Knasel et al., 2000). Personal barriers are formed by the learning person, for example, negative attitude towards learning and unpleasant learning experience, exaggerated anxiety over learning results, lack of learning skills, problems related to family responsibilities. Usually, practical barriers are related to resources, for example, lack of money and the price of learning programmes and tools, lack of time, limited possibilities to use information resources, difficult traffic, etc. Organisation barriers are influenced by the organisation in which a person is learning. This is, for example, learners' groups that are made inadequately, when the interests, level of acquired knowledge and motivation differ among learners; there is a lack of learning support, learning consultations, low level of competences etc.

As a very important organisation barrier is named the hierarchical structure of the organisation: in such organisation, persons have few possibilities to learn from one another and rarely share ideas beyond the limits of their departments. Social barriers are associated with the social environment of the learner. In different social layers and subcultures, learning is evaluated differently. Personal attitudes towards learning are usually influenced by the fact in which place knowledge and education is ranked among the value priorities of family and relatives. For example, unfavourable spouse's attitude towards learning may be a strong learning barrier.

When learning is realised in the plane of constructivist theory, it can be claimed that the life itself and the roles performed by the person encourage development, interest and learning. Social role is a certain behaviour that is related to the personal activity and occupied position. A person performs tens of social roles per day that change together with the changing social environment activity and its context. Accordingly, various social roles can motivate and hinder learning.

Super $(1980,1990)$ identified nine primary life roles: child, student (pupil, student, etc.), worker, partner, parent, citizen, homemaker, leisurite and pensioner. He noted as well that each life role tends to be played in a particular "theatre": worker at the work, student at the university, mother or father and homemaker at home, leisurite at the café etc. According to Super, such link of roles with particular places was logical and 
understandable in certain periods but not in the 21st century. Modern technologies make it possible to perform the role of the worker of many career areas in any place in the world: comfortably sitting at the home computer, enjoying the sun at the beach or coffee at the open café. Studying can be performed not only in auditoriums, laboratories or libraries. The role of a student can be successfully performed even in Antarctica by logging to university databases via internet. The blurring lines between "life scenes" and roles (when several roles are performed at the same time and space) make balancing life-role activity an even greater challenge for the modern man.

The overlapping and confusion of roles leads to their superficial performance, non-usefulness (White, Klein, 2002), threatens with dissatisfaction in the life quality, low-self-realisation and professional burnout. When aiming to balance life-roles, a person should listen to his/her and other people expectations and clearly know what, how, when and, most importantly, why it should be done. According to Niles, Herr and Hartung (2002), under the conditions of role strain, the level of human self-consciousness has to be much higher, in comparison to the time when the boundaries between life-roles and their scenes were much clearer.

When deciding when, where and how to perform various life-roles, a person should have a clear understanding of possible life-roles and the importance attributed to them. Super, Savickas and Super (1996) stress that social elements that constitute a life, which are arranged in a pattern of core and peripheral roles. This arrangement or life structure forms the basic configuration of a person's life. Usually, only several roles are called core in human life. What are these roles is determined mainly by the person's value system. If a person devotes enough time and energy to perform the core (according to his/her opinion) roles, satisfaction with life and the sense of fulfilment ensue. However, when the system of responsibilities related to roles is disbalanced (too much time and energy is wasted to perform unimportant, peripheral roles), a person is experiencing inner conflict and role tension, which is perceived as barriers when confronting with the responsibilities of a certain role (Marks, MacDermid, 1996).

The question arises, how the life-roles, their distribution and importance vary from the aspect of human development. Super, Sverko (1995) revealed the change of life-roles in the life-career rainbow theory. Accord- 
ing to this theory, from birth to death, human life is like a rainbow, a path across the sky. Every colour of the rainbow is a life-role. When a man is born, he/she does not have many roles. The most important of them is the role of a child to his/her parents. When starting to go to school, a person is burdened by an important role of a pupil (or learner). At sixteen years, he/she is obliged to perform the role of a citizen of the state. When starting to work, the role of the worker is experienced (in fact, a variety of roles is related to work activity). When starting a family, a person has to take the role of a husband or wife. When a child is born, the role of father or mother is played all day and night. When the parents are starting to get old and require care, the role of their child acquires a different meaning. When starting to live independently, acquiring a home, a person should take the role of the homemaker.

Not all roles require equal responsibilities. It is quite easy to combine some roles (for example, to be a good worker or colleague, mother and a homemaker); whereas, it is difficult to combine other roles. The role of a mother is distinguished as demanding many efforts and difficultly compatible with career roles (Čyžiūtè, 2007). The role of father is compatible with career roles easier due to the gender stereotypes that have been formed in the society.

The abundance of life-roles and the burden of responsibility related to them highly differ during different life periods. The most of roles appear in the middle life period when a person is a child of his/her parents, a father (mother) for his/her children, a partner in the family, a worker, a student, a leisurite, a citizen, etc. It becomes a challenge to combine all roles in this stage, the priorities should be clearly named, and many things have to be sacrificed for more important ones. The concept of sandwich generation is used to describe this period of man's development (McCrindle, 2014) by stressing multilayer responsibility of a man due to the variety of roles.

In conclusion, it should be stressed that adult learning motives and barriers change and vary according to the prevailing social roles at different periods of one's life. This dynamics of adult learning motives and barriers is mostly influenced by the importance and compatibility of acquired social roles, responsibility areas and spaces of a person and other factors. 


\section{Methodology}

In response to the questions that have been raised in this article: what motives encourage adults to learn, what barriers hinder their learning, how are the adult learning motives and barriers and their dynamics related to the change of social roles, the aim of this research is to reveal the dynamics of learning motives and barriers in the context of changing human life roles.

After the theoretical analysis, it has been decided to choose qualitative research. The narrative research strategy has been chosen in order to reveal respondents' biographical facts and reflect on their learning experience. Narrative inquiry explores life experiences by using the language of "story". The researcher of the narrative uses the themes or categories to restore the field texts. The stories of adult learners reveal the changing learning motives and barriers.

In order to reveal the biographical facts of the informants, reflecting upon their learning experience, the narrative research strategy was chosen. This method makes it possible to preserve the flexibility and complexity of thoughts and freedom of expression. It allows focusing on the experiences of participants and suits for the analysis of life stories. Narrative inquiry explores life experience using the language of "story". According to Labov, W., \& Waletzky, J. (1997), the narrative story can reveal the essence of an unknown phenomenon. In this particular case it is an appropriate method to reveal the motives and the barriers for adult learning.

Narrative is a method in which the researcher recreates the texts to facilitate the reader to experience the lives or events described. The respondents wrote self-reflective narratives where they described learning experiences in the context of life events. Self-reflections were provided in written form. In the self-reflective narratives, the respondents had to write their personal stories under the title "My Learning Path". The following questions were provided as well: 1) what and how did you learn during your life; 2) what encouraged you to learn at every stage of life; 3) what difficulties have you encountered. The first question aims to reveal the dynamics of learner's role intensity in the context of other life-roles. The second question helps to reveal learning motives, and the third disclose 
the learning barriers. These writings have been analysed, and the results of the research have been prepared.

Qualitative content analysis was applied for the analysis of the narrative data (Miles \& Huberman, 1994). Qualitative analysis of content was based on the systemic step performance: 1) identifying the manifest categories, while referring to the 'key' words; 2) dividing the content of categories into subcategories; 3 ) identifying intersecting elements in the category/subcategory contents; 4) interpreting the content data. The analyzed texts reflect human experiences, attitudes, feelings, concretize the context, in this case - motives and barriers for learning. Texts are analyzed consistently, step by step, by dividing the analyzed content into the units. It has been selected as the analysis method of the narrative, because it allows decoding the meanings that are hidden in the content and helps to interpret data from the narrative content. The text reflects personal experiences, preferences, feelings and specifies context, which is the context of changing life-roles in this case. The text is analysed coherently, gradually, by dividing the analysed content into units.

Sample. The qualitative data was gathered in March - April 2016 in Kaunas, Lithuania. The sample consisted of 30 individuals (18 women and 12 men), aged 35 to 65 years (average -42 years) participating in professional training courses (formal education) and developing their general competencies. These adult learners were chosen because they have various learning experiences and can reflect on them. There has been prepared 30 self-reflections.

Ethics. In research were implemented the following ethical principles (Howe \& Moses, 1999): voluntary participation - respondents participated in the study on a voluntary basis; informed consent - respondents were informed about research aim and content, the meaning and importance of the research were also explained; respect to individual's dignity - respondents with free will were able to reject to participate in the study, also they had the right to refuse to provide the information or they had the right to ask questions and receive information about research; anonymity - in research the anonymity were assured regarding their provided information; their names, surnames were not fixed and in the study were provided only generalized and summarized findings. 


\section{Results of the Research on Dynamics of Learning Motives and Barriers in the Context of Changing Life Roles}

Overall, this paper contributes to the literature, an understanding of factors motivating adult learners in higher education. This understanding, especially by both instructors and administrators of higher education has the potential of enhancing the success of students pursuing graduate studies. Moreover, the study provides a useful starting point for further inquiry.

When analysing respondents' answers, the statements have been divided into two categories "Dynamics of Learning Motives" and "Dynamics of Learning Barriers". These categories are described further in detail linking them to the changing social roles, the nature of learning and its importance in the context of man's development.

In the analysis of the dynamics of learning motives, there have been singled out three subcategories of statements that reveal differences of learning motives during different periods of human life.

The subcategory of learning motives in youth includes learning motives that mostly influence young age learners. When reflecting on learning experiences, the respondents perceive learning at general and higher education schools as an investment in the future. They state that in youth, they were mostly motivated by the distant future carrier vision: "While young, you should seek education. You know that there will be nothing without education. I have realised this in the eighth grade already..." (X18). The vision is very abstract for some respondents ("in order to create a good life, you have to study well at the university", X11), but very clear and highly motivating for the others: "I had a dream to become a university teacher. It is a difficult path to choose, I needed good grades and, of course, knowledge. I tried very hard and studied more than my course friends. It was not difficult, because I knew why I was doing this" (X24).

When recalling learning in formal education system during the period of childhood, adolescence and early youth, the respondents perceive learning as work, and the motivation to learn is a matter of course. For example, X19 is writing: "Back then, learning was my main responsibility, work, occupation. I was thinking how to learn and account for every subject. The last thing I was thinking about was how to use this knowledge. Parents 
constantly reminded me that education is in the first place, and friends, backyard and clubs will wait. There were no incentives or morals. You are learning because you are a pupil. How there can be different?"

A common learning motive related to young age is belonging to the group of learners. It is mostly noticed in the reflections from the period of general education school ("I got into a smart class, where it was a shame not to learn; everyone was learning well and was proud of it," says $\mathrm{X7}$ ) and remembering studies at the higher education school ("we were all trying very hard not for the scholarship, but to avoid being the last in the group", X6; "in evenings, I went to additional French courses that were free of charge, financed by the university. I was not so interested in learning this beautiful language, but more in being together with the French group, I went there like into celebration and came back flying", X13).

Further analysing learning motives of adults, the first group encompasses external motives that is primarily related to the professional life of respondents. Moreover, these statements determine the factors that exceptionally influence the learning of adults and other persons experiencing social role overload.

When entering to maturity, according to respondents, learning acquires different meaning and purpose. The most usually mentioned learning motive of adults is financial reward and consequently a better carrier position. For example, respondent X1 says that "economic motives are important; though lacking behind businessman in material wealth, the state employees, to which I belong, are not equally payed. Persons that have greater and wider education climb the carrier steps quicker and get bigger wages."

Relating learning with the possibility to improve personal financial situation, the respondents understand the limitations and temporality of such learning motives. In this case, learning becomes another burden besides other performed social roles and obtained responsibilities: "I do not expect good learning results, because my learning is influenced not by the internal, but only by external motives. I came to learn in order to retain my work position (after a change in law, I cannot work at school). Because of that I feel bad for my daughter, which I see only in the evenings, and I do not have family weekends" (X2).

Adult learners are encouraged to learn from the issues arising in various spheres of their life. Usually, they appear in professional activity 
and are associated with retaining personal competitiveness in the labour market. The respondents acknowledged that if not for the constantly changing world of work, the role of the learner could be forgotten for some time. For example, X3 states that "The most important learning motive is invariably changing and advancing electronics and information processing technologies that require updating knowledge constantly". Learning is motivated by the challenges related to other life-roles: mother, father, leisurite etc. Adults are trying to find solutions to life problems by employing various forms and methods of learning. For example, X5 states that "The real activity proposed by life conditions is always inspiring my motivation to obtain new knowledge. The organisation of children leisure and their extracurricular activities set the aim to find out more about the areas of pedagogy, children rights and accounting. When I realised I could no longer understand my own children, one crisis went after another, and I decided to attend psychological trainings for parents".

Another important aspect is learning expectations. Adults expect that learning will result in quick and concrete benefits. The expectation to improve life quality acts as an important learning motive. For instance, as X14 says, "the most important is that trainings would be not only for training, that afterwards, something would change in my life. It I attend a seminar or some sort of lecture, I am always thinking how will I or my family benefit from it". While learning, the changes in life quality of a particular person are revealed in different aspects. These include health and family nutrition improvement ("I was attending raw food courses and learnt to how cook healthy and tasty. The life significantly improved after these courses, I should have signed into them earlier...", X12), enrichment of leisure ("when I learnt Spanish, the vacations acquired different quality", X9) and facilitation of household life ("I know that when I will learn to drive, I will be able to do much more, than now", X16).

The fixed internal learning motives encompass statements that are rather related to the personal traits than to the learner's age or performed social roles.

Curiosity, inquisitiveness could be named as an important internal learning motive, which is typical only for a small number of adult participants of this research. Usually, children are learning due to their curiosity, but adults rarely devote time for something from which they do not expect practical benefits. However, the existence of this internal 
motive may be found in some stories of respondents that participated in this research. For example, X7 says that "all my life I have been and still am seeking for knowledge. Curiosity is my natural state; I cannot stop learning new things. Sometimes my learning is very impractical, for example, something like chiromancy or face-reading, but when it is interesting, I do it without thinking, I have to satisfy my curiosity".

Adults are motivated to learn by strong self-respect as well. This learning motive is quite rarely mentioned and is associated with the person's character, maybe with the expressed tendency towards leadership. For example, X1 tells that "Knowledge helps me to feel better at work, family and among friends. I do not want to be left out thinking, deciding, searching, I do not like only to listen, have no opinion. It is unpleasant to obey, it is better to lead or at least offer logic and reasonable solutions. Human self-respect is an important learning motive".

The aiming at personal development is another internal learning motive typical for human beings at every stage of life ("it is important to grow and develop as a person, train my skills, widen horizons", X9). However, other roles that are performed by a person highly influence the manifestation of this learning motive. At such stage of life when many social roles and responsibilities related to them are experienced, the aim of personal improvement becomes of secondary importance. For example, X26 says that "when I did not have children, I attended yoga courses, read self-improvement books, did not miss any events. Now, I only can remember that time, I hardly do what is necessary... I got rusty".

During the analysis of the dynamics of learning barriers, it has been noticed that two groups of statements revealing differences of learning barriers during different stages of human life have stood out in this category. The subcategory of learning barriers in youth encompasses statements describing learning obstacles experienced at school and university. The respondents reconstruct their stories and evaluate their experiences from the position of a mature man; thus, a certain kind of personal moralisation (in adolescence, youth) can be noticed. For example, laziness is named as one of the learning barriers, X29 states that "nothing got in the way, everything was taken care of, you should only learn; but laziness still took over..."

Another learning barrier that is usually mentioned is the lack of motivation and self-motivation. This personal learning barrier is linked 
to the week interest in taught subjects ("I was not interested, I had to force myself, which was not always successful...", X4, limited abilities ("I was never good at mathematics, and I did not like it. In university, I was learning it as well, but I did not understand why should I put efforts", X11).

When recalling learning in youth, persons of mature age stress that the main obstacle was "light headedness" or lack of responsibility. After the analysis of stories, a clear domination of other life-roles over the learner's role has been noticed. Even though respondents do not name it directly, on the contrary, they stress that "learning was such work at that time", the initiation of other life-roles (becoming a partner, housemaker, worker) had an influence on the limited performance of the learner's role. For example, X15 say that "well, learning was not the only thing on my mind [...], when I fell in love in the second course, I had to terminate studies, [...] I have made academic debts because I could not concentrate and perform tasks".

In the further analysis of the distinguished adult learning barriers of respondents, the research data helped to name the main learning obstacles. It is the lack of time that was emphasized first by almost all respondents. For example, X1 say that "It does not matter how carefully you plan and distribute hours of the day, it is difficult to combine into them children and own health care, education needs, work, studies, trips to places, homework, literature search and reading, household troubles... due to the lack of time, of course, one or another activity suffers. Knowing that this intensive learning is temporary, positive organisation of the learning process, support of family and relatives and the happiness of participation in the group activities help to overcome the barriers". It is clear that this learning barrier is linked not only to simple time planning abilities, but also to the abundance and intensity of life-roles. Adults studying in the informal education system complained about the length of learning programmes ("The biggest barrier is the lack of time. Another one is too long, not always logically composed learning programmes", X3) stressing the feature typical for the adult learning: structured learning and seeking of quick results.

Another important learning barrier is the change of learning programmes, which is becoming a heavy burden for personal or family budget, because the expenses related to other life roles have to be reduced. For example, X7 tells that "I am building a log house and instead of paying 
for studies, I could buy materials for the roof. However, I understand that diploma will help me to retain work position".

Social learning barriers have been mentioned very rarely, but they have been named as well, especially in relation to the social environment of the learner. For example, X9 acknowledges that "I am mostly frustrated by the negative spouse's attitude towards my learning, I have no one to lean on when it is difficult". An adult person who is determined to learn unbalances social roles by changing the comfort zones of family members and relatives and is faced with relatives disagreement, resistance and blaming.

Lack of self-confidence, fear that it is already too late to start, lack of determination are the learning barriers that are quite rarely mentioned by the adults; they are related to personal qualities and negative experience of learning. However, the mentioning of age as a barrier is related to the performance of other life-roles that require a lot of time and energy: "It is too late to learn at this age, no energy and endurance. I have an important position at work and no right or possibilities to rest at the workplace" (X8).

Another important learning obstacle is the lack of necessary competences. Adults tend to seek quick learning results, but the embracement of taught subject fundamentals usually requires a lot of time and efforts, and the gaps of knowledge and abilities become a learning obstacle. For example, X6 say that "The main learning barrier is poor knowledge of Lithuanian; thus, the learning process does not bring a lot of happiness. Due to my age, I cannot learn the language well enough to feel good".

After the data analysis, it has been revealed that benefit and meaning aspects are very important for the adult learning, because, first of all, learning is time investment, and when the intensity of performed social roles is high, the time criteria becomes very significant. Another important aspect is the prevalence of external motives that move personal learning motive into the second place. The fact that some respondents are forced to learn due to their professional activity determines their inner dissatisfaction with the learning process as they are sacrificing their leisure or time that could be devoted to their family.

In the evaluation of learning barrier dynamics, it could be stated that the practical barriers prevailing in the respondents' answers, i.e., the lack of time and the change of learning programme prices, are supplemented by the disagreement of the close social circle, which is another impor- 
tant social barrier. Thus, this determines weaker expression of internal motives, and learning is chosen inevitably due to career or other aims related to the professional life.

\section{Conclusions}

Adults are encouraged to learn by different motives depending on their performed social roles. External motives related to future professional activity, career and social circle prevail at the young age (i.e., when learning at school or university). However, personal barriers prevail in the expression of learning barriers. This is influenced by the society's attitude towards the performance of pupil and student roles and the value attitudes of surrounding people that partially control it.

Later on, external motives, i.e., motives related to career, professional life and life quality, prevail in the expression of motives when performing the role of the worker. Whereas, the personal motives emerging from the desire of self-realisation and personal development remain overshadowed and are of secondary importance. The dynamics of learning barriers is closely related to social roles and their change. In this case, the influence of practical and social barriers is mostly noticed (Knasel et al., 2000); while, the personal barriers, such as lack of self-confidence and the lack of knowledge base and competencies, are less significant.

Thus, there has been noticed a conflict among the performed social roles of adults, i.e., worker and mother/father, which is influenced by the lack of time and the dissatisfaction arising from it, because not enough time is devoted for children. In other words, external learning motives and barriers that are directly related to professional activity and social environment prevail in the period when he/she is active in the labour market. Even though it could be stated that proactive learning motives prevail in the respondents' self-reflections, the narrow expression of internal learning motives does not provide full satisfaction, and learning becomes inevitable due to the requirements of the labour market.

\section{References}

Chao Jr. R. Y. (2009), Understanding the Adult Learners' Motivation and Barriers to Learning. Educating the Adult Educator: Quality Provision and Assessment 
In Europe. Conference Proceedings, European society for research on the education of adults (ESREA), p. 905-916.

Čyžiūtė J. (2007), Veiklios moters socialiniai vaidmenys šeiminès partnerystès kontekste, „Filosofija. Sociologija“, 18(2), p. 55-63.

Drucker P. (1993), Post-Capitalist Society. NY. Harper Business.

Gage N. L., \& Berliner D. C. (1992), Educational Psychology (5th ed.). Boston: Houghton Mifflin.

Howe K. R., \& Moses M. S. (1999), Ethics in educational research. Review of research in education, 24, p. 21-59.

Huberman M. A., Miles M. B. (1994). Qualitative Data Analysis. A Sourcebook of New Methods, Newbury Park, Sage Publications.

Kilroy D. A. (2004), Problem based learning, "Emergence Medicine Journal", 21(4), p. 411-413.

Knasel E., Meed J., \& Rossetti A. (2000), Learn for your life: a blueprint for careerlong learning. Financial Times Prentice Hall.

Labov, W., \& Waletzky, J. (1997). Narrative analysis: Oral versions of personal experience.

Marks S. R., \& MacDermid S. M. (1996), Multiple roles and the self: A theory of role balance, "Journal of Marriage and the Family", 2, p. 417-432.

McCrindle M. (2014), The ABC of XYZ. Understanding the Global Generations, McCrindle Researche Pty Ltd.

Niles S. G., Herr E. L., \& Hartung P. J. (2002), Adult career concerns in contemporary society, Adult career development: Concepts, issues and practices, p. 2-18.

Psichologijos žodynas (1993), Vilnius: Mokslo ir enciklopedijų leidykla.

Ramsay J., \& Sorrell E. (2007), Problem-Based Learning: An Adult-education-oriented Training Approach For SH\&E Practitioners, "Professional Safety", 52(9), p. 41-47.

Rubenson K. (2011), Adult Learning and Education, Elsevier Ltd.

Savickas M. L., Nota L., Rossier J., Dauwalder J. P., Duarte M. E., Guichard J., Soresi S., Van Esbroeck R., Van Vianen A. E. (2009), Life designing: A paradigm for career construction in the 21st century, "Journal of vocational behaviour", 75(3), p. 239-250.

Sogunro O. A. (2015), Motivating Factors for Adult Learners in Higher Education. "International Journal of Higher Education", 4(1), p. 22-37.

Stanišauskienè V. (2007), Gyventojų įtraukimas į besimokančio miesto vystyma, Kaunas: Technologija. 
Stipek D. J. (2002), Motivation to learn: From theory to practice (4th ed.), Boston: Allyn \& Bacon.

Super, D. E. (1980), A Life-span, Life-space Approach to Career Development, "Journal of Vocational Behavior", 16, p. 282-298.

Super D. E. (1990), A Life-Span, Life-Space Approach to Career Development, [in:] Career Choice and Development, eds. Brown, D. Brooks L. \& Associates, San Francisco: Jossey-Bass, p. 197-261.

Super D. E., Savickas M. L., \& Super G. M. (1996), The life-span, life-space approach to careers, [in:] Career choice and development, eds. D. Brown \& L. Brooks, p. 121-170.

Super D. E., \& Sverko B. E. (1995), Life roles, values, and careers: International findings of the Work Importance Study. Jossey-Bass.

Trivette C. M., Dunst C. J., Hamby D. W., \& O'herin C. E. (2009), Characteristics and consequences of adult learning methods and strategies, "Winterberry research syntheses", 2(2), p. 1-33.

White J. M., \& Klein D. M. (2002), Family theories: Understanding families, Thousand Oaks, CA: Sage Publications. 